\title{
Summit on Global Sustainability in Engineering: Rationale and Planning Phase
}

\author{
Robert Nagel, $\mathrm{PhD}^{1}$, Jacquelyn Nagel, $\mathrm{PhD}^{1}$, Ivan Esparragoza, $\mathrm{PhD}^{2}$, Linda Schmidt, $\mathrm{PhD}^{3}$, and Jorge Rodriguez, \\ $\mathrm{PhD}^{4}$ \\ James Madison University, USA, nagelrl@jmu.edu, nageljk@jmu.edu \\ The Pennsylvania State University, USA, iee1@psu.edu \\ University of Maryland, USA, 1schmidt@umd.edu \\ Western Michigan University, USA, jorge.rodriguez@wmich.edu
}

\begin{abstract}
The growing global awareness on developing products, structures, and processes in a sustainable fashion is demanding the incorporation of sustainability-related topics in engineering curricula. One of the biggest challenges, however, is teaching students to appreciate and understand the complex and global nature of sustainability challenges. Although some efforts have been made in academia to incorporate sustainability, work remains to identify the most effective techniques to teach our students-especially in less quantifiable contexts (e.g., global and cultural). Toward meeting this challenge, the authors are preparing a Summit to bring together scholars from across the Americas with expertise in teaching and learning techniques for sustainability. The main goal of the Summit is to bring together a small group of researchers to explore pedagogical models to introduce global sustainability awareness in engineering education, and for the group of researchers to formulate action plans for developing and deploying learning modules that introduce global sustainability awareness to students at their home institutions. This paper reports on the preliminary work performed in preparation for the Summit. It introduces the "Engaged Learning" approach developed as a part of this project to guide Summit participants in developing and deploying learning activities, and it provides planned assessment activities.
\end{abstract}

Keywords-Sustainability, engineering education, teaching strategies, pedagogy, learning environments, assessment.

Digital Object Identifier

(DOI):http://dx.doi.org/10.18687/LACCEI2016.1.1.200

ISBN: 978-0-9822896-9-3

ISSN: 2414-6390

$14^{\text {th }}$ LACCEI International Multi-Conference for Engineering, Education, and Technology: "Engineering Innovations for Global Sustainability", 20-22 July 2016, San José, Costa Rica. 


\title{
Summit on Global Sustainability in Engineering: Rationale and Planning Phase
}

\author{
Robert Nagel, $\mathrm{PhD}^{1}$, Jacquelyn Nagel, $\mathrm{PhD}^{1}$, Ivan Esparragoza, $\mathrm{PhD}^{2}$, Linda Schmidt, $\mathrm{PhD}^{3}$, \\ and Jorge Rodriguez, $\mathrm{PhD}^{4}$ \\ ${ }^{1}$ James Madison University, USA, nagelrl@jmu.edu, nageljk@jmu.edu \\ ${ }^{2}$ The Pennsylvania State University, USA, iee1@ psu.edu \\ ${ }^{3}$ University of Maryland, USA, 1schmidt@umd.edu \\ ${ }^{4}$ Western Michigan University, USA, jorge.rodriguez@wmich.edu
}

\begin{abstract}
The growing global awareness on developing products, structures, and processes in a sustainable fashion is demanding the incorporation of sustainability-related topics in engineering curricula. One of the biggest challenges, however, is teaching students to appreciate and understand the complex and global nature of sustainability challenges. Although some efforts have been made in academia to incorporate sustainability, work remains to identify the most effective techniques to teach our students-especially in less quantifiable contexts (e.g., global and cultural). Toward meeting this challenge, the authors are preparing a Summit to bring together scholars from across the Americas with expertise in teaching and learning techniques for sustainability. The main goal of the Summit is to bring together a small group of researchers to explore pedagogical models to introduce global sustainability awareness in engineering education, and for the group of researchers to formulate action plans for developing and deploying learning modules that introduce global sustainability awareness to students at their home institutions. This paper reports on the preliminary work performed in preparation for the Summit. It introduces the "Engaged Learning" approach developed as a part of this project to guide Summit participants in developing and deploying learning activities, and it provides planned assessment activities.
\end{abstract}

Keywords-Sustainability, engineering education, teaching strategies, pedagogy, learning environments, assessment.

\section{INTRODUCTION}

The growing global awareness on developing products, structures, and processes in a sustainable fashion is demanding the incorporation of sustainability-related topics in the engineering curricula [1]. New graduates need to develop the necessary knowledge, skills, and attitudes to find feasible, desirable, and technically-sound solutions by balancing the social, environmental, and economic pillars of sustainability while considering the local and global impact in the decision making process. Today's engineering students, unfortunately, tend to have a narrow view of sustainability, thinking of it as simply local environmental impact or energy efficiency [2] without taking into account the multi-dimensional context of sustainability. Further, a review of these published strategies for teaching sustainability reveals that approaches tend to focus primarily on a single local context of sustainability instead of a holistic approach [3]. This leaves educators with a challenge: How can we effectively teach our students to appreciate and understand the complex and global nature of sustainability challenges?

Digital Object Identifier (DOI): http://dx.doi.org/10.18687/LACCEI2016.1.1.200 ISBN: 978-0-9822896-9-3

ISSN: $2414-6390$
Although some efforts have been made in academia to incorporate sustainability education into engineering education, work remains to identify the most effective techniques to teach our students-especially in less quantifiable contexts (e.g., global and cultural). Davidson et al. [4] point to a "lack of high quality education materials like textbooks and other course readings covering current challenges" as a key issue. Indicating as well that there is minimal incentive in the traditional academic reward structure (e.g., promotion and tenure) to publish one's teaching strategies, and those publications that are available tend to only state the benefits of an approach leaving out the modules, methods, and strategies necessary for implementation in one's class.

This need for an engineering education containing a broad and holist view of sustainability is also required by ABET in Outcome $\mathrm{H}$, which states that engineering students should receive "the broad education necessary to understand the impact of engineering solutions in a global, economic, environmental, and societal context" [5].

Perhaps it is in response to external pressures, such as the one quoted above from ABET, but Davidson et al. note in a commentary following their 2014 National Science Foundation funded workshop, Sustainability in Engineering Courses and Curricula, that "hundreds of engineering programs are simultaneously attempting to develop SE [(sustainable engineering)] education materials, but are doing so in relative isolation" [4]. This points toward a need for face-to-face meetings that bring together scholars and educators to develop a network to work together toward this goal of not only developing teaching modules, but also ensuring that the teaching modules are effective.

Such an approach was taken by a group of 12 lecturers from Colombia, Panama, Ecuador, and the United States together with 28 graduate students, post-doctoral students, and junior faculty from the United States and Latin America by working together at the National Science Foundation sponsored (Grant \#1242268) "Pan-American Advanced Studies in Manufacturing Innovation through Sustainable Design" (PASI) at the Universidad del Norte in Barranquilla, Colombia. The PASI group explored sustainability topics related to design, materials, production, distribution, tools and methods, and engineering education. Multidisciplinary teams formed to explore future directions for new research collaborations and industrial applications as well as needs for

$14^{\text {th }}$ LACCEI International Multi-Conference for Engineering, Education, and Technology: "Engineering Innovations for Global Sustainability", 20-22 July 2016, San José, Costa Rica. 
continued education and training. At this PASI, a group of researchers chose to explore pedagogy and content related to sustainability education in engineering design. In the PASI outcomes report, it was noted "that relationships established at the workshop led to ongoing collaborations for research and educational exchanges between the organizers, lecturers, and early career participants that have borne fruit and others that are still being cultivated" [6] indicating that these face-to-face meetings positively impact the aforementioned goal of developing networks of scholars and educators around a common interest and need.

Continuing efforts first started at the PASI, a group of five PASI participants (the authors) is now focusing on a Summit to bring together scholars and educators from across the Americas with expertise in teaching and learning techniques for sustainability to explore pedagogical models to introduce global sustainability awareness in engineering education. Through this Summit, researchers will have an opportunity for not just exchange of technical knowledge, but also cultural exchange. Exposure to how others view sustainability issues will be key in developing awareness of faculty members, and the authors hypothesize that this facultymember awareness will positively influence learning activities, future collaborations and implementations, as well as student learning at home institutions. The Summit is a very specific effort that will focus on the context of the effect of globalization on the recognized pillars of sustainability.

By having a group of researchers from the Americas (i.e., Brazil, Canada, Chile, Colombia, Ecuador, Mexico, Panama, and United States), it is expected that a common perspective on global sustainability can be established, without losing the local perspective. Latin America, Canada, and the USA are well-situated to develop and strengthen academic and industrial partnerships that will define this subject. In today's world it difficult to consider engineering challenges with a narrow and local perspective; now it is imperative to tackle problems with multinational and multidisciplinary approaches. There are specific knowledge, skills, and attitudes that relate to those approaches, and in the field of sustainability, it is even more imperative to have common core values containing the global perspective while still keeping in mind the local environment.

The main goal of the Summit will be reached by attaining the following two objectives:

1) identify characteristics, methods, and models of a pedagogical approach to introduce knowledge and dimensions of sustainability, including geographical and cultural parameters, into engineering curricula, and

2) define a plan to create learning modules that move students from awareness (knowledge) to strategic processing.

The aim of this paper is to report the activities carried out in preparation for the Summit and introduce the "Engaged Learning Template" that will serve as a guideline for participants to share their personal knowledge and experience but also reflect and discuss their ideas, receive feedback, create global partnerships, and enhance previous experiences. Other activities include assessment for evaluation of the Summit, and compilation of presentations and reading materials that will serve to steer the efforts of the participants.

\section{BACKGROUND}

A "sustainability in engineering education" search online produces close to 32 million hits. This might give the idea that there is abundant information about the topic already available; however, a more careful look at the findings shows that the information is disperse and the definitions, approaches, and understanding of sustainability vary as more literature is available.

From the engineering perspective, there have been multiple efforts to define sustainability. One notable effort by Mihelcic et al. [7] in 2003 states sustainability as "the design of human and industrial systems to ensure that humankind's use of natural resources and cycles does not lead to diminished quality of life due either to losses in future economic opportunities or to adverse impacts on social conditions, human health, and the environment" in an effort to include the three pillars of sustainability. Despite the comprehensive definition given above, there are still many researchers who consider sustainability as an effort to protect the environment [8-11] thus ignoring global, economic, social, and other dimensions of sustainability. The work by Christ et al. [12] recognizes the social, economic, and environmental pillars of sustainability citing the work of other researchers in the field [13-15], and the need of an interdisciplinary approach to sustainability $[7,16]$, but still the emphasis is being placed on the environmental dimension.

Sustainability has been recognized as a multi /interdisciplinary and global discipline. There have been various approaches to include the global perspective into the curriculum. Most of the efforts are in the context of existing projects. For example, Brigham Young University (BYU) has multidisciplinary teams working abroad [17,18], Case Western Reserve University offers a course that uses global simulation software GlobeSight for class work [19], California State University-Northridge implemented a graduate level curriculum in sustainable manufacturing [20], or a modular teaching approach in industrial engineering training [21]. Additionally, the work by Weisz and Clark [22] highlights the need of an interdisciplinary approach to deal with the complexity of sustainability based on the society-nature coevolution. There is a strong interrelation between human activities and the surrounding environment making it difficult to understand them separately [23]. Sustainability challenges are associated with interconnected problems including political, economic, social, cultural, psychological, technological, and environmental issues that cannot be considered separately and should be integrated by an interdisciplinary approach to study sustainability [24].

$14^{\text {th }}$ LACCEI International Multi-Conference for Engineering, Education, and Technology: "Engineering Innovations for 


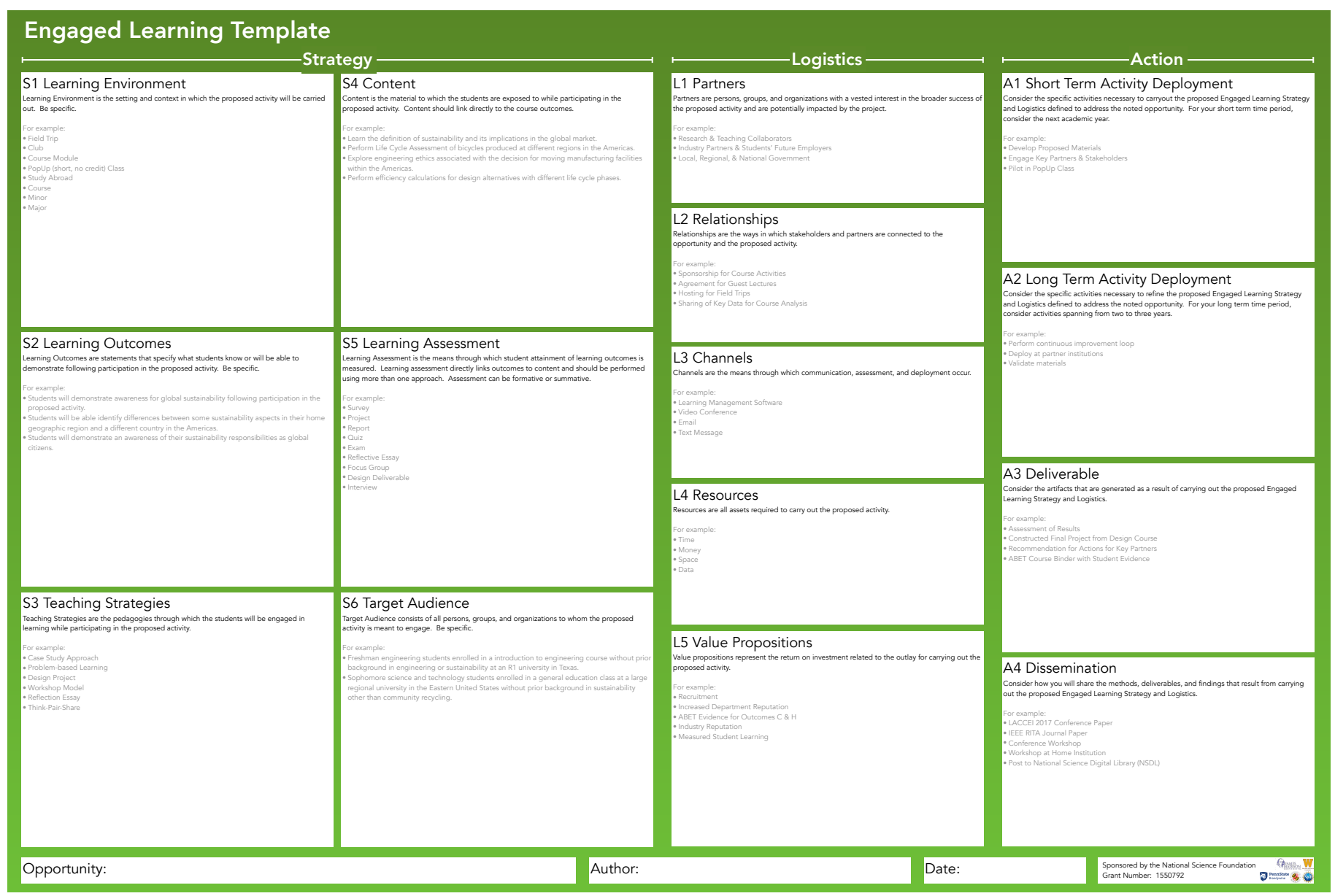

Fig. 1 Engaged Learning Template Poster.

Work by students also seems to emphasize a single environmental pillar of sustainability neglecting the social and economic aspects. One study of a university in the southeastern USA $(\mathrm{n}=552)$ found that students exposed to sustainability content in a course are aware of it but lack a well-rounded and holistic understanding of the topic [25]. The Higher Education Academy of the UK published a report in 2015 about students' attitudes and skills for sustainable development $(n>5000)$; when students were asked to describe sustainable development, "the environmental dimension also continues to be more prominent..." [26].

Developing sustainable solutions and designs is considered ill-structured and open-ended, and it requires consideration of environmental, social, and economic factors. These tasks are technically and culturally complex, demanding a multi or interdisciplinary pedagogy [27]. The teaching challenge is clear and the learning rewards include development of interdisciplinary competence [28]. Cues for teaching sustainable development can also be found in the business schools that are embracing the Principles for Responsible Management Education (PRME) initiative established between the United Nations and business schools [29]. Erskine and Johnson explored student opinions on effective means to teach PRME principles $(\mathrm{n}=183)$, reporting sustainability case studies ranked as $9^{\text {th }}$ out of 35 approaches. Ranking above case studies were scholarships, internships, field trips, international learning opportunities, and extra credit for participation in projects [30].

\section{PROPOSED APPROACH}

The proposed approach consists of a framework that is used to identify and define engaged learning activities to incorporate sustainability in the engineering curriculum. This approach is similar to the one popularized by the Business Model Generation [31] and applied to educational activities with the Learning through Service (LTS) Program Model Blueprint by Paterson et al. [32-34]. The LTS Blueprint was designed for a variety of different learning enterprises "including a whole integrated program, academic courses, elective courses, or even an extracurricular experience" [34]. When applying Learning through Service Program Model Blueprint in the workshops for the Engineering Faculty Engagement in Learning Through Service project, a total of 57 participants (36 in development workshops [33]) and 21 participants in an American Society for Engineering Educators workshop [34]) used the LTS Blueprint to refine, reflect, or 
develop their own service learning courses. Swan et al. [33], found that "most participants (from the 36 development users) commented favorably on the use of the LTS Blueprint as a framework to 1) structure their LTS efforts, and 2) provide a methodology to continually review and enhance desired goals and values that their LTS effort intends to provide."

The framework that has been developed for the Summit is entitled, Engaged Learning Template, and it is presented herein as Version 2.0. Like with the LTS Blueprint, it was designed with flexibility in mind. It was anticipated that Summit attendees might be working on a variety of different projects ranging from co-curricular opportunities (e.g., Pop Up classes) to multi-course sequences that might combine into a minor. Also, like with the LTS Blueprint the goal was to have a document that could be used for both design and reflection. The Engaged Learning Template was further developed to meet a need Davidson et al. in [4] noted that "too many engineering courses are taught without clear and welldesigned learning objectives and assessment tools to enable quantified information on whether the course objectives have been achieved." An emphasis was placed on developing learning outcomes that map to learning strategies and content. Toward this need, mappings between course learning outcomes, course content, course strategies, and learning assessment are enumerated in the text prompts. The Engaged Learning Template consists of three categories:

(1) Strategy, which relates to the intention of the proposed activity, and it is the description of the learning environment (S1), learning outcomes (S2), teaching strategies (S3), content (S4), learning assessment (S5), and target audience (S6) for a particular activity;

(2) Logistics, which relates to the requirements of the proposed activity for sustainable deployment, and it is the partners (L1), relationships (L2), channels (L3), resources (L4), and associated value proposition (L5); and

(3) Action, which relates to the deployment and deliverables associated with the specific proposed activity, and it is short term (A1) and long term (A2) activity deployment, deliverables (A3), and dissemination (A4).

Figure 1 provides the Engaged Learning Template as will be provided to the Summit attendees (printed as a $1.60 \mathrm{~m}$ by $1.07 \mathrm{~m}$ poster), and for added clarity, further descriptions for each item are provided in Tables I, II, and II, respectively.

TABLE I.

ENGAGED LEARNING TEMPLATE-STRATEGY SECTION

\begin{tabular}{|l|l|}
\hline \multicolumn{2}{|c|}{ Strategy } \\
\hline S1 Learning Environment & S2 Learning Outcomes \\
Learning environment is the setting & Learning Outcomes are statements \\
and context in which the proposed & that specify what students know or \\
activity will be carried out. Be & will be able to demonstrate following \\
specific. & participation in the proposed activity. \\
For example: & Be specific. \\
- Field trips & For example: \\
- Club & - Students will demonstrate \\
- Course module & awareness for global sustainability \\
- Pop Up (short no-credit) course & following participation in the \\
\hline
\end{tabular}

\begin{tabular}{|c|c|}
\hline $\begin{array}{l}\text { - Study abroad } \\
\text { - Course } \\
\text { - Minor } \\
\text { - Major }\end{array}$ & $\begin{array}{l}\text { proposed activity. } \\
\text { - Students will be able identify } \\
\text { differences between some } \\
\text { sustainability aspects in their home } \\
\text { geographic region and then a } \\
\text { different country in the Americas. } \\
\text { - Students will demonstrate an } \\
\text { awareness of their sustainability } \\
\text { responsibilities as global citizens. }\end{array}$ \\
\hline $\begin{array}{l}\text { S3 Teaching Strategies } \\
\text { Teaching Strategies are the } \\
\text { pedagogies through which the } \\
\text { students will be engaged in learning } \\
\text { while participating in the proposed } \\
\text { activity. } \\
\text { For example: } \\
\text { - Case study approach } \\
\text { - Problem-based Learning } \\
\text { - Design project } \\
\text { - Workshop model } \\
\text { - Reflection essay } \\
\text { - Think-Pair-Share }\end{array}$ & $\begin{array}{l}\text { S4 Content } \\
\text { Content is the material to which the } \\
\text { students are exposed to while } \\
\text { participating in the proposed activity. } \\
\text { Content should link directly to the } \\
\text { course outcomes. } \\
\text { For example: } \\
\text { - Learn the definition of } \\
\text { sustainability and its implications } \\
\text { in the global market. } \\
\text { - Perform Life Cycle Assessment of } \\
\text { bicycles produced at different } \\
\text { regions in the Americas. } \\
\text { - Explore engineering ethics } \\
\text { associated with the decision for } \\
\text { moving manufacturing facilities } \\
\text { within the Americas. } \\
\text { - Perform efficiency calculations for } \\
\text { design alternatives with different } \\
\text { life cycle phases. }\end{array}$ \\
\hline $\begin{array}{l}\text { S5 Learning Assessment } \\
\text { Learning Assessment is the means } \\
\text { through which student attainment of } \\
\text { learning outcomes is measured. } \\
\text { Learning assessment directly links } \\
\text { outcomes to content and should be } \\
\text { performed using more than one } \\
\text { approach. Assessment can be } \\
\text { formative or summative. } \\
\text { For example: } \\
\text { - Survey } \\
\text { - Project } \\
\text { - Report } \\
\text { - Quiz } \\
\text { - Exam } \\
\text { - Reflective essay } \\
\text { - Focus group } \\
\text { - Design deliverable } \\
\text { - Interview }\end{array}$ & $\begin{array}{l}\text { S6 Target Audience } \\
\text { Target Audience consists of all } \\
\text { persons, groups, and organizations to } \\
\text { whom the proposed activity is meant } \\
\text { to engage. Be specific. } \\
\text { For example: } \\
\text { - Freshman engineering students in } \\
\text { an introduction to engineering } \\
\text { course without prior background in } \\
\text { engineering or sustainability at an } \\
\text { R1 university in Texas. } \\
\text { - Sophomore science and } \\
\text { technology students in a general } \\
\text { education class at a large regional } \\
\text { university in the Eastern United } \\
\text { States without prior background in } \\
\text { sustainability other than } \\
\text { community recycling. }\end{array}$ \\
\hline
\end{tabular}

TABLE II.

ENGaged Learning TeMPlate-Logistics SeCtion

\begin{tabular}{|c|c|}
\hline \multicolumn{2}{|c|}{ Logistics } \\
\hline $\begin{array}{l}\text { L1 Partners } \\
\text { Partners are persons, groups, and } \\
\text { organizations with a vested interest } \\
\text { in the broader success of the } \\
\text { proposed activity and are potentially } \\
\text { impacted by the project. } \\
\text { For example: } \\
\text { - Research \& Teaching } \\
\text { Collaborators } \\
\text { - Industry Partners \& Students' } \\
\text { Future Employers } \\
\text { - Local, Regional, \& National } \\
\text { Government }\end{array}$ & $\begin{array}{l}\text { L2 Relationships } \\
\text { Relationships are the ways in which } \\
\text { stakeholders and partners are } \\
\text { connected to the opportunity and the } \\
\text { proposed activity. } \\
\text { For example: } \\
\text { - Sponsorship for Course Activities } \\
\text { - Agreement for Guest Lectures } \\
\text { - Hosting for Field Trips } \\
\text { - Sharing of Key Data for Course } \\
\text { Analysis }\end{array}$ \\
\hline $\begin{array}{l}\text { L3 Channels } \\
\text { Channels are means through with } \\
\text { communication, assessment, and }\end{array}$ & $\begin{array}{l}\text { L4 Resources } \\
\text { Resources are all assets required to } \\
\text { carry out the proposed activity. }\end{array}$ \\
\hline
\end{tabular}




\begin{tabular}{|l|l|}
\hline deployment occur. & For example: \\
For example: & - Time \\
- Learning Management Software & - Money \\
- Video Conference & - Space \\
- Email & \\
- Text Messages & \\
\hline L5 Value Propositions & \\
Value propositions represent the & \\
return on investment related to the & \\
outlay for carrying out the proposed & \\
activity. & \\
For example: & \\
- Recruitment & \\
- Increased Department reputation & \\
- ABET evidence for Outcomes C \& & \\
- H & \\
\hline
\end{tabular}

TABLE III.

ENGAGED LEARNING TEMPLATE-ACTION SECTION

\begin{tabular}{|l|l|}
\hline \multicolumn{2}{|c|}{ Action } \\
\hline A1 Short Term Activity & A2 Long Term Activity \\
Deployment & Deployment \\
Consider the specific activities & Consider the specific activities \\
necessary to carryout the proposed & necessary to refine the proposed \\
Engaged Learning Strategy and & Engaged Learning Strategy and \\
Logistics defined to address the & Logistics defined to address the \\
noted opportunity. For your short & noted opportunity. For your long \\
term time period, consider the next & term time period, consider activities \\
academic year. & spanning from two to three years. \\
For example: & For example: \\
- Develop proposed materials & - Perform continuous improvement \\
- Engage key partners \& & loop \\
stakeholders & - Deploy at partner institutions \\
- Pilot in Pop-Up Class & - Validate materials \\
\hline $\begin{array}{l}\text { A3 Deliverables } \\
\text { Consider the artifacts that are } \\
\text { generated as a result of carrying out } \\
\text { the proposed Engaged Learning }\end{array}$ & Consider how you will share the \\
Strategy and Logistics. & methods, deliverables, and findings \\
For example: & that result from carrying out the \\
- Assessment of results & proposed Engaged Learning Strategy \\
- Constructed final project from & and Logistics. \\
design course & For example: \\
- Recommendation for actions for & - LACCEI 2017 Conference Paper \\
key partners & - IEEE RITA Journal Paper \\
- ABET course binder with student & - Wonference Workshop \\
evidence & - Post to National Science Digital \\
\hline
\end{tabular}

The Summit is a 4-day event taking place at James Madison University (JMU) at the end of March 2016. The activities during the event are scheduled from Wednesday (Day 1) evening to Saturday (Day 4) mid-day. In the evening of Day 1, to help motivate the attendees, a keynote event will start the Summit. This speaking event includes three speakers from local industry; each will speak about the importance of sustainability to their industry and company, and from their perspective as a practitioner.

There are two additional speaking events that will occur on Day 2 and the focus is on two key topics for the goals of the Summit: a) what? (i.e., the topics, tools, and competencies for teaching sustainability), and b) how? (i.e., pedagogy and programs for teaching sustainability). Each of these speaking events will have two speakers offering different perspectives on the topics. Following each talk, there will be a panel discussion to motivate further conversation.

On Day 3, there will be two speakers that will cover the topic of where? (i.e., how is sustainability taught in different parts of the Americas). The intention is to help attendees make connections between the differences in sustainability education across the Americas. The final speaker on Day 3 will cover assessment to help attendees measure the learning attainment of the activity being designed during the Summit. On Day 4, attendees will share their final completed templates, and the group will provide additional feedback so that a valuable resource will be available in the following months.

It is expected that throughout the Summit, attendees will work individually and as apart of an affinity group toward completing the template for a learning activity that will be deployed at their home institution. On Day 2, the focus will be to identify opportunities, which will be accomplished through two think-pair-share active learning activities. The first will focus on eliciting what each attendee is teaching at their home institution with respect to sustainability. The second will focus on eliciting how each attendee is teaching sustainability at their home instruction. Shared responses to these activities will provide a map of what and how for sustainability education across the Americas, as represented by the attendees from Brazil, Panama, Mexico, Colombia, Chile, Ecuador, Canada, and the US. Based on this information, attendees will all collectively identify opportunities for new learning activities that include a global perspective. Establishing such learning activity opportunities allows for the formation of affinity groups that will serve as support during the Summit and afterwards. On Day 3, individuals working independently, but with the support of their affinity groups, will complete their templates. High resolution pictures of each completed Engage Learning Template will be captured for assessment purposes, and participants will be allowed to take their completed Engaged Learning Template home for further refinement, reflection, and implementation.

\section{ASSESSMENT}

Assessment will occur using three mechanisms:

(1) pre/post survey

(2) collection and coding of attendee templates

(3) capturing of what, how, and where for sustainability education across the Americas from workshop activities.

The pre/post survey has been finalized for the Summit. Planned pre-survey questions are the following:

- Explain your understanding of sustainability.

- What contexts do you consider as a part of sustainability? (Check all that apply)

$\begin{array}{cl}\circ & \text { Environmental } \\ \circ & \text { Economic } \\ \circ & \text { Social } \\ \circ & \text { Individual }\end{array}$




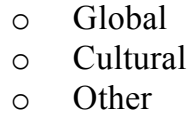

- How are you engaging students in sustainability education?

$\begin{array}{cl}\circ & \text { Required course } \\ \circ & \text { Elective course } \\ \circ & \text { Capstone } \\ \circ & \text { Field trip } \\ \circ & \text { Study abroad } \\ \circ & \text { Student club } \\ \circ & \text { Minor } \\ \circ & \text { Other }\end{array}$

- How is your Institution engaging students in sustainability education?

$\begin{array}{cl}\circ & \text { Required course } \\ \circ & \text { Elective course } \\ \circ & \text { Capstone } \\ \circ & \text { Field trip } \\ \circ & \text { Study abroad } \\ \circ & \text { Student club } \\ \circ & \text { Minor } \\ \circ & \text { Other }\end{array}$

- Who (departments/units/offices) at your University is engaging students in sustainability education?

- What teaching strategies are you using to engage students in sustainability education?

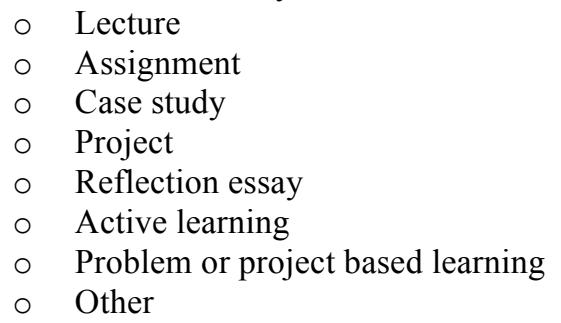

- Are you engaging your colleagues in sustainability education?

- How are you engaging your colleagues in sustainability education? If you are currently not, then please write N/A.

- How are your colleagues engaging you in sustainability education?

- What sustainability frameworks/structure have you used when developing your student engagement activities?

- What educational frameworks/structure have you used when developing your student engagement activities?

- What partners have you worked with when developing your student engagement activities? Consider partners internal and external to your University.

- What resources have you used when developing your student engagement activities? Be as specific as possible.
- $\quad$ Rate the value placed on sustainability education at your University using the following scale.

Planned post-survey questions are the following:

- Explain your understanding of sustainability.

- What contexts do you consider as a part of sustainability? (Check all that apply)

$\begin{array}{cl}\circ & \text { Environmental } \\ \circ & \text { Economic } \\ \circ & \text { Social } \\ \circ & \text { Individual } \\ \circ & \text { Global } \\ \circ & \text { Cultural } \\ \circ & \text { Other }\end{array}$

- How do you plan to engage students in sustainability education?

$\begin{array}{cl}\circ & \text { Required course } \\ \circ & \text { Elective course } \\ \circ & \text { Capstone } \\ \circ & \text { Field trip } \\ \circ & \text { Study abroad } \\ \circ & \text { Student club } \\ \circ & \text { Minor } \\ \circ & \text { Other }\end{array}$

- How do you plan to engage your colleagues in sustainability education?

- Rate the usefulness of the Engaged Learning Template compared to your current resources for your engagement activities.

- Was the Engaged Learning Template useful compared to the sustainability engagement techniques you currently use?

- Rate the usefulness of the Engaged Learning Template compared to your current educational framework/structure for your engagement activities.

- What connections formed at the Summit will you maintain following the Summit?

- What connections do you plan to develop once you return to your home institution?

- What is the likelihood that you will change your engagement strategy as a result of attending this Summit?

- How will you change your engagement strategy as a result of attending this Summit?

- Rate your interest in putting together a paper and presentation at LACCEI 2017 using the following scale.

- What were the most beneficial aspects of attending this workshop?

- What was the most valuable session of the workshop?

- What was the least valuable session of the workshop? 
- Was there a workshop activity that you needed more time for to complete?

- Do you feel confident on your level of accomplishment at the workshop?

Participant responses to a variety of workshop activities will be qualitatively and quantitatively analyzed in addition to the survey results. Assessment results will be reported in a follow-up article.

\section{SUMMARY \& FUTURE WORK}

The literature is rich in discussing sustainability in engineering education, but practical modules to be incorporated in the curriculum are scarce and in most cases do not have an interdisciplinary scope. The aim of the reported pre-Summit work is to develop learning activities based on the Engage Learning Template approach with a global and interdisciplinary scope that includes the three pillars of sustainability. The mid-term goal is to pilot the proposed learning activities at different grade levels in engineering and assess them for continuous improvement as well as establish collaborations across the Americas for teaching global sustainability perspectives in engineering. The long-term goal is to create a global community with the purpose of exchanging information, building a collection of learning activities, and to promote educational activities for sustainability in engineering education.

\section{ACKNOWLEDGMENT}

This work was supported by the National Science Foundation (NSF) Grant Number 1550792. Any opinions, findings, and conclusions or recommendations expressed in this material are those of the authors and do not necessarily reflect the views of National Science Foundation.

\section{REFERENCES}

[1] I. de Vere, G. Melles, and A. Kapoor, "An ethical stance: Engineering curricula designed for social responsibility," Proceedings of the 18th International Conference on Engineering Design (ICED 11), Impacting Society through Engineering Design. Lyngby/Copenhagen, Denmark, Vol. 8, 2011.

[2] B. R. Allenby, "The Theory and Practice of Sustainable Engineering," Prentice-Hall, $1^{\text {st }}$ edition, 2011.

[3] M. Arsat, J.E. Holgaard, and E. De Graff, "Three dimensions of characterizing courses for sustainability in engineering education: Models, approaches and orientations," Proceedings 3rd International Congress on Engineering Education: Rethinking Engineering Education, The Way Forward, ICEED, Kuala Lampur, Malaysia, 2011, pp. 37-42.

[4] C.I. Davidson, B.R. Allenby, L.M. Haselbach, M. Heller and W.E. Kelly, "Educational materials on sustainable engineering: Do we need a repository?," Elementa: Sci. Anthro., 4(1), 2016, pp. 000089.

[5] ABET, Criteria for Accrediting Engineering Programs. Engineering Accreditation Commission, 2011.

[6] R.B. Chinnam, K. Haapala, I. Esparragoza, K. Jackson, G.O. Kremer, "Pan-American Advanced Studies Institute on Manufacturing Innovation through Sustainable Design Report," National Science Foundation, 2013. [Online] Available:

http://grantome.com/grant/NSF/IIA-1242268 [Accessed: 6- May- 2016].

[7] J. R. Mihelcic, J. C. Crittenden, M. J. Small, D. R. Shonnard, D. R. Hokanson, Q. Zhang, H. Chen, S. A. Sorby, V. U. James, J. W. Sutherland, and J. L. Schnoor, "Sustainability science and engineering: the emergence of a new metadiscipline," Environ. Sci. Technol., 37, 2003, pp. 5314-5324.

[8] B. J. Brown, M. E. Hanson, D. M. Liverman, and R. W. Meredith, "Global sustainability: Toward definition," Environmental Management, vol. 11, n6, 1987, pp. 713-719.

[9] R. Duffell, "Toward the environment and sustainability ethic in engineering education and practice," J. Professional Issues Eng. Educ. Pract., vol 124, n3, 1998, pp. 78-90.

[10] P. Glavic, "Sustainability engineering education," Clean Techn. Environ. Policy, 8, 2006, pp. 24-30.

[11] M. Lu, "Integrating sustainability onto the introduction of environmental engineering," J. Prof. Issues Eng. Educ. Pract., 141(2), 2015.

[12] J. A. Christ, J. L. Heiderscheidt, M. Y. Pickenpaugh, T. J., Phelan, J. B. Pocock, M. S. Stanford, G. E. Seely, P. C. Suermann, and T. M. Twesme, "Incorporating sustainability and green engineering into a constrained civil engineering curriculum," J. Prof. Issues Eng. Educ. Pract., 141(2), 2015.

[13] J. Lubichenco, "Entering the century of the environment: a new social contract for science," Science, 279(5350), 1998, pp. 491-497.

[14] D. R. Hokanson, Q. Zhang, J. R. Cowden, A. M. Troschinetz, J. R. Mihelcic, and D. M. Johnson, "Challenges to implementing drinking water technologies in developing world countries," Environ. Eng. Appl. Res. Pract., I, 2007, pp. 31-38.

[15] R. Beddoe, R. Constanza, J. Farley, E. Garza, J. Kent, I. Kubizewski, L. Martinez, T. McCowen, K. Murphy, N. Myers, Z. Ogden, K. Stapleton, and J. Woodward, "Overcoming systemic roadblocks to sustainability: the evolutionary redesign of worldviews, institutions, and technologies," Proc. Nat. Acad. Sci., 106(8), 2009, pp. 2483-2489.

[16] J. Fiskel, T. Graedel, A. D. Hecht, D. Rejeski, G. S. Sayler, P. M. Senge, D. L. Swackhamer, T. L. Theis, "EPA at 40: bringing environmental protection into the $21^{\text {st }}$ century," Environ. Sci. Technol., 43(23), 2009, pp. 8716-8720.

[17] J. Geddes, W. V. Wilding, and R. Lewis, "Sustainability and Impact of Global Projects", Proc. of Annual ASEE Conference and Exposition, 2009, pp. 14.1107.1-10.

[18] G. M. Warnick, "Global Competence: Its Importance for Engineers Working in a Global Environment", Proc. of Annual ASEE Conference and Exposition, 2011, pp. 22.748.1-30.

[19] S. N. Sreenath, M. D. Mesarovic, and A. M. Vali, "Education on Globalization and Sustainability for Engineers", Proc. of Annual ASEE Conference and Exposition, 2003, pp. 8.462.1-19.

[20] B. Li, S. J. Gandhi, and L. Ding, "Curriculum design for sustainability of globally integrated manufacturing", Proc. of Annual ASEE Conference and Exposition, 2015, pp. 26.431.1-9.

[21] D. Nazzal, J. Zabinski, A. Hugar, D. Reinhart, and K. Madani, "Introduction of Sustainability Concepts into Industrial Engineering Education: a Modular Approach", Advances in Engineering Education, 2015, pp. 1-30.

[22] H. Weisz and E. Clark, "Society-nature coevolution: interdisciplinary concept for sustainability," Geografiska Annaler: Series B Swedish Society for Anthropology and Geography, 2011, pp. 281-287.

[23] L. H. Gunderson, L. H., and C. S. Holling, editors. Panarchy: understanding transformations in human and natural systems. Island Press, Washington, D.C., USA, 2002.

[24] P. Jones, D. Selby, and S. Sterling, editors. Sustainability education; perspectives and practice across higher education. Earthscan, London, New York, 2010.

[25] P. Fisher and E. McAdams, "Gaps in sustainability education", Int. J of Sus. in Higher Ed, vol. 16, no. 4, pp. 407-423, 2015.

[26] Heacademy.ac.uk, "Student attitudes towards, and skills for, sustainable development (2015) | Higher Education Academy", 2016. [Online]. Available: https://www.heacademy.ac.uk/resource/student-attitudestowards-and-skills-sustainable-development-2015. [Accessed: 13- Feb2016].

[27] P. Eagan, T. Cook and E. Joeres, "Teaching the importance of culture and interdisciplinary education for sustainable development", Int. $J$ of Sus.in Higher Ed, vol. 3, no. 1, pp. 48-66, 2002. 
[28] M. Barth, J. Godemann, M. Rieckmann and U. Stoltenberg, "Developing key competencies for sustainable development in higher education", Int. J of Sus. In Higher Ed, vol. 8, no. 4, pp. 416-430, 2007.

[29] "PRME - About Us - Overview", Unprme.org, 2016. [Online]. Available: http://www.unprme.org/about-prme/index.php. [Accessed: 13- Feb- 2016].

[30] L. Erskine and S. Johnson, "Effective Learning Approaches for Sustainability: A Student Perspective", Journal of Education for Business, vol. 87, no. 4, pp. 198-205, 2012

[31] A. Osterwalder and Y. Pigneur, Business Model Generation. Hoboken, NJ: John Wiley \& Sons, Inc., 2010.

[32] A. R. Bielefeldt, K. Paterson, C. Swan, O. Pierrakos, D. O. Kazmer, and A. Soisson, "Spectra of Learning Through Service Programs," presented at the 120th ASEE Annual Conference and Exposition, Atlanta, CA, 2013.

[33] C. Swan, A. R. Bielefeldt, K. Paterson, D. O. Kazmer, O. Pierrakos, A. Soisson, and B. G. Tucker, "Workshops for the Engineering Faculty Engagement in Learning Through Service (EFELTS) Project: Development and Initial Findings," presented at the 120th ASEE Annual Conference \& Exposition, Atlanta, GA, 2013.

[34] K. G. Paterson, C. W. Swan, D. Kazmer, A. R. Bielefeldt, G. Rulifson, and O. Pierrakos, "Designing Value in Engineering Learning Through Activities Using a Blueprint Model," International Journal for Service Learning in Engineering, Humanitarian Engineering and Social Entrepreneurship, vol. Special Issue, pp. 64-83, 2013.

$14^{\text {th }}$ LACCEI International Multi-Conference for Engineering, Education, and Technology: "Engineering Innovations for Global Sustainability”, 20-22 July 2016, San José, Costa Rica. 